\title{
IMPACT OF CROP DIVERSIFICATION ON LIVELIHOOD IMPROVEMENT AND SUSTAINABLE LAND MANAGEMENT IN CHATTOGRAM HILL TRACTS OF BANGLADESH
}

\author{
Rahman, M. M., W. Parvin, N. Sultana and S. A. M. Tareq \\ Silviculture Genetics Division, Bangladesh Forest Research Institute, Chattogram - 4000, Bangladesh
}

\begin{abstract}
The study was conducted at Sorai union of Lama Upazilla under Bandarban district of Chattogram Hill Tracts. It was found that total 19 plant species including bamboos, timbers and fruit crops have been widely cultivated in the area. Among the species five bamboo (Mitinga, Baijja Muli, Borak and Kali), six timbers (Acacia, Eucalyptus, Garjon, Teak, Gamar and Rubber) and eight fruits (Mango, Olive, Papaya, Guava, Coconut, Hog pulm, Orange and Betel nut) were recorded. Bamboo based agro-forestry modules were developed and practiced which produced a very good cropping diversification to sustain the crop productivity, protection of land sliding, soil erosion, water shade and soil fertility in the hill areas. It has been observed that farmers' have a very good positive attitude and perception in diversified cropping system to get better yields than mono cropping agricultural practice at their home- stead and farm- lands. It has a very good opportunity to make the crop diversification for sustainable production of hill farming and resource management.
\end{abstract}

Key words: Crop diversification; Sustainable land management; Shifting cultivation; Livelihood.

\section{INTRODUCTION}

The hilly area of Bangladesh is enriched with many important resources like forest, agriculture, water, etc. and an excellent natural ecosystem. Once the landscape was covered with various forest types and green vegetation but gradually became denuded due to unscientific hill resource management. The ethnic people of the Chattogram Hill Tracts (CHTs) have been practicing a traditional farming system of shifting cultivation (jhum) for decades. In the past, the shifting cultivation has served the needs of many generations with goods and services in a sustainable manner. Now, the sustainability of traditional shifting cultivation is being disappeared due to dramatically increasing population arising from both endogenous growth and in-migration by large numbers of plain landers. In the face of increasing landuse pressures, farmers no longer can afford the luxury of long fallow periods that allow recovery of the secondary forest and rejuvenation of exhausted soil fertility. Therefore, the fallow period or jhum cycle under shifting cultivation has been shortened from 10-15 years to 2-3 years. Frequent cultivation on slope land with short (2-3 years) jhum cycle has resulted in accelerated run-off of water and soil erosion, decline soil fertility, land degradation, reduced tree growth and crop yields, and threatening living environment as a whole. Due to shortened jhum cycle along with other technical weaknesses, the shifting cultivation is no more in a position to cope with future needs of the hill farmers. As a result more than $80 \%$ of the population of this region now depends on stagnant and/or declining farming practices. The decline of productivity of these existing farming practices is now a major concern. The land degradation process is exacerbated by the excessive rainfall in association with cultivation on nude hill slope. This process ultimately results in accelerated surface water run-off, soil erosion, soil compaction, low water infiltration, declining soil fertility, land degradation, low crop yields and tree growth, regression of various forest types, bamboos etc., and the degraded environment as a whole. This in turn, has brought about the wider demand and supply gap in all sorts of forest/agroforestry products. It was found that, the production of paddy in jhum cultivation has been declined to 4-5 times in comparison to several decades back (Paul 2001). Present productivity of forests has declined to a range of 1.5-2.5 m3 during the last 20 years (Khan and Millate-e-Mustafa 2001). Due to shortened fallow 
period / jhum cycle along with other technical weaknesses the shifting cultivation (jhum) is no more in a position to cope with future needs of the hill farmers. On the contrary, the socio-economic development in the upland hills is closely related to the land productivity, and sustainability of modern hill cultivation is closely related to soil conservation and productivity (Nair 1984, Young 1989, Garrity 1999). In view of this, setting a balance between production and conservation through developing an appropriate hill production system has been envisaged.

Therefore, an alternative farming system is required in the region to create sustainable land-use systems, improve farmers' living conditions, reduce deforestation, and protect the watershed and bioresources. Multi-cropping/agroforestry is a viable land use option for uplands management and can increase and sustain crop productivity in the uplands and can improve a system of environmental conservation. Moreover, as a land-use system, cropping diversification has been increasingly regarded as an effective and low-cost method for minimizing the processes of degradation associated with land cultivation and for the retention of the local ecosystems. The goal of the study was to improve livelihood security of hill farmers of Chattogram Hill Tracts (CHTs) through application of bio-diverse ecofriendly agroforestry practices.

\section{METERIAL AND METHODS}

Sorai union of Lama Upazilla under Bandarban district of Chattogram Hill Tracts was selected as the study site (Fig. 1.). It is located at 40 kilometers south from Bandarban main city and 20 kilometers North of Lama Upazilla. It comprises with 9 wards and the total population is 13,292.

Ethnic and Bengali communities have been living together in this union. Four ethnic communities such as Marma, Tanchanga, Murang and Tripura are living there. Most of the people are to depend on agricultural practices and they are small household owner. The ethnic people usually practice their traditional farming system Jhum- the shifting cultivation. Participatory Rural Appraisal (PRA) method with developed questionnaires was followed to select the targeted farmers group and to identify their problems, needs and potentials.

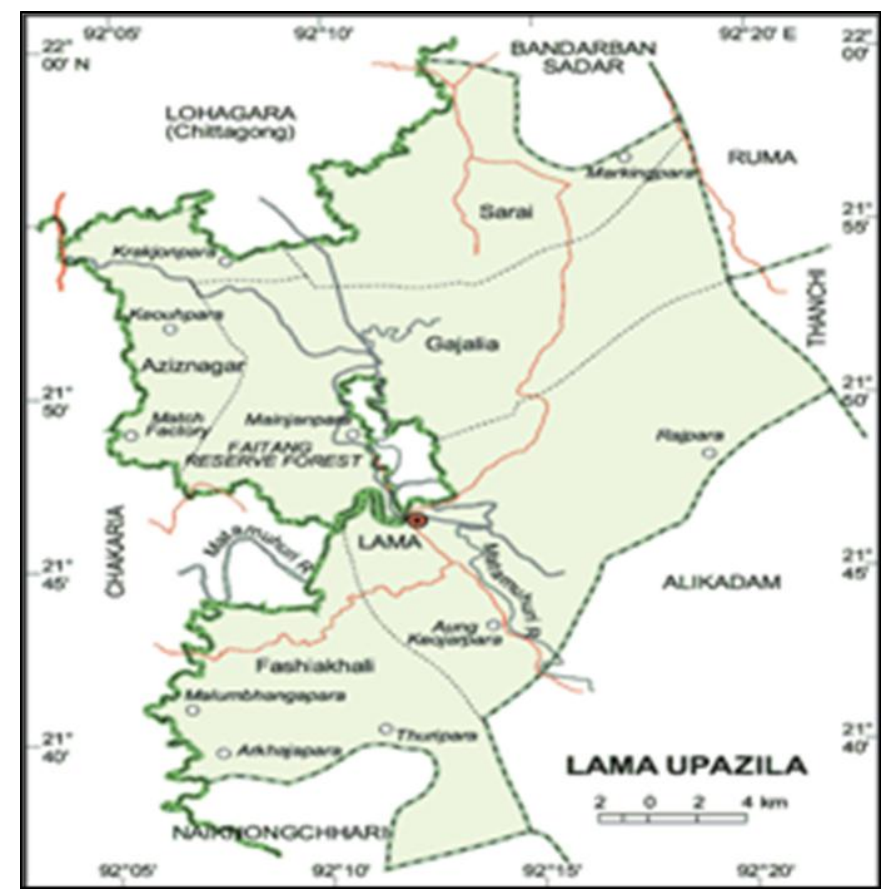

Fig. 1. Sorai union of Lama Upazilla, Bandarban district of CHTs. 
The pre-intervention status of the selected farmers was evaluated through case studies/surveys. In the process, the existing farm resources, assets, liabilities, present use of resources, existing farming practices and technologies used, level of input used and outputs obtained, performances of different enterprises, income and expenditure status assessed for each farm household.

Based on the pre-intervention status, the system performance was analyzed in the context of existing biophysical and socio-economic environment of the farm and constraints and potentials identified. To ensure maximum utilization of existing farm resources, alternate/new packages of technology was identified and finally selected on the basis of farmers' option.

\section{Data collection and analysis}

The farmers' attitude and perception regarding practicing an alternative method of agricultural practice instead of their traditional jhum cultivation was focused in this study. So the farmers of the study area were selected as the target group and the primary data were collected from the field using mixed method followed by semi-structured questionnaire. The sample size was 60 selected farmers who practice the traditional jhum cultivation were the sampling unit. Mixed methods were used to collect the field data. Framers attitude and perceptions regarding practicing agroforestry were assessed along with their socio-economic conditions by the help of the questionnaire. Different indicators for accessing the contributions of agroforestry practice in reducing poverty at the study area were selected for this study. These indicators were income status, housing condition, sanitation condition, status of the production of agricultural crops, homestead and cropland agroforestry species and perception on importance of trees. The collected data were reviewed, sorted and analyzed systematically considering the objectives of the study.

\section{RESULTS AND DISCUSSION}

Primary data were collected and analyzed to find out the existing farm practices, problems, needs, potentials, level of input use and outputs obtained, farm income and expenditure status etc. Based on the land ownership the selected farm households were categorized in three types. These exercises revealed that maximum farm households were at marginal level having a range of land 0-10 acres (Fig. 2).

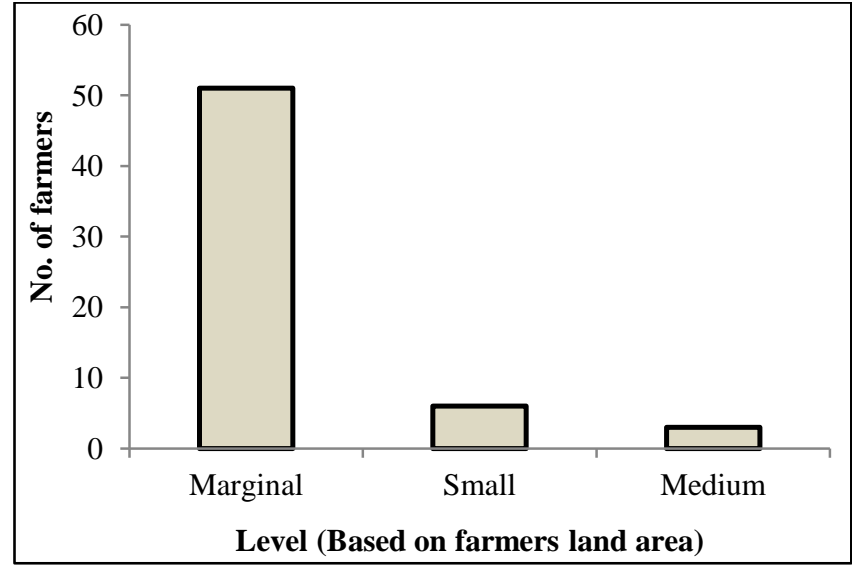

Fig. 2. Types of farm household.

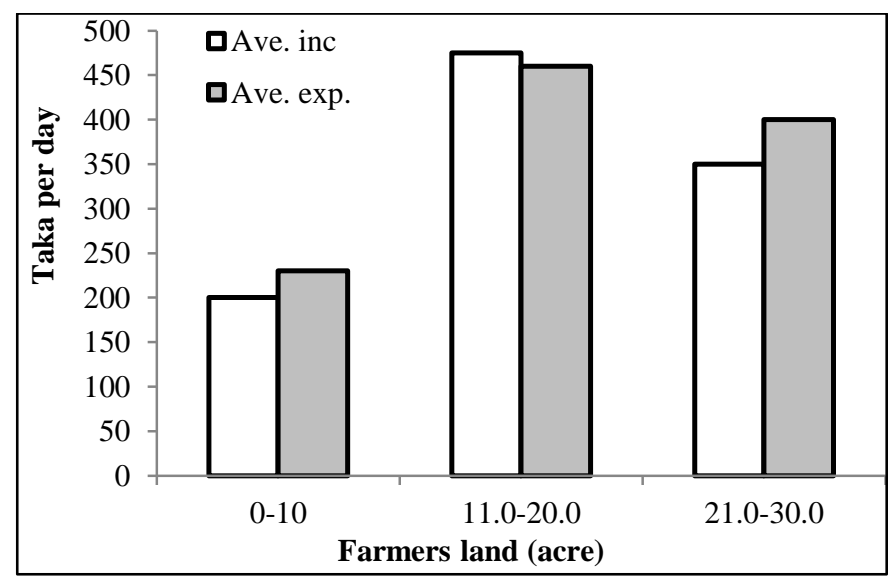

Fig. 3. Comparative income and expenditures of farm household.

The daily income and expenditures of each farm household are presented in Fig. 3. It was found that all the three types of farm owners have a gap between their income and expenditures. Traditionally the farmers have been cultivating agricultural crops, timber plants, fruits plants and vegetables; mostly paddy. Some of them have livestock and fisheries as well. As the study site is the hilly region of 
Bangladesh, most of the farmers have perennial timber and non-timber trees, fruit plants and annual vegetables. Diversified tree species are grown in the homestead and farm lands. Among these species Acacia (Acacia auriculiformis Benth.) is dominant followed by Teak (Tectona grandis L.f.), Eucalyptus (Eucalyptus camaldulensis Dehnh.), Garjon (Depterocarpus sp.), Gamar (Gmelina arborea Roxb.) and Rubber (Hevea brasiliensis (Willd. ex A. Juss.) Müll. Arg. (Fig. 4).

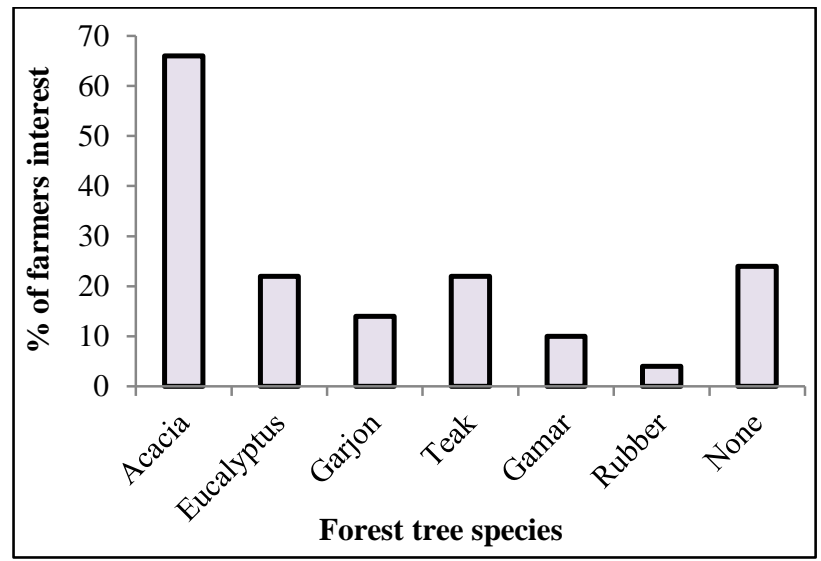

Fig. 4. Farmers response on tree species.

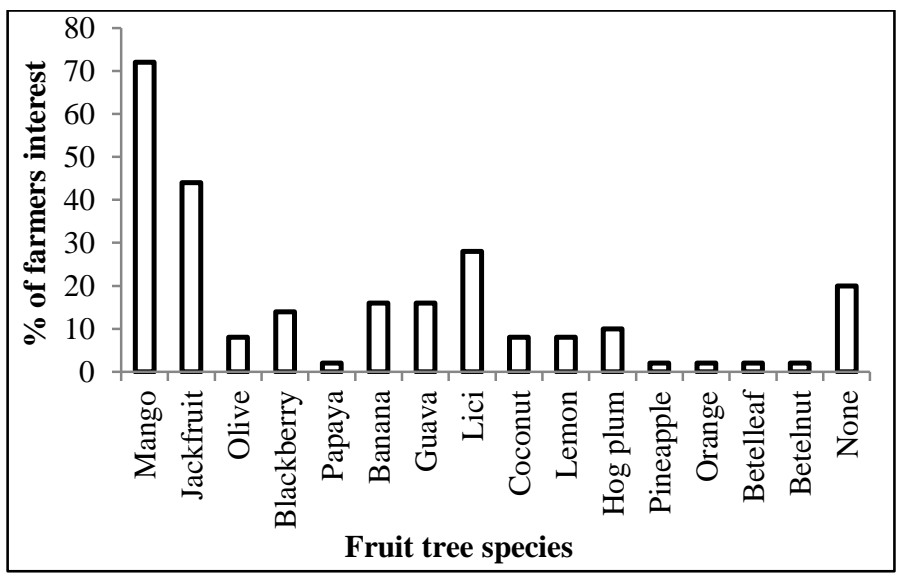

Fig. 5. Farmers interest on fruit crops.

The maximum $66 \%$ farmers have their interest on Acacia (Acacia auriculiformis) due to the first growing nature whereas $24 \%$ farmers have no timber plants. In case of fruit plants maximum $72 \%$ farmers have their interest on Mango followed by Jackfruit. Mangoes and Jackfruits are chosen due to their food and timber value (Fig. 5).

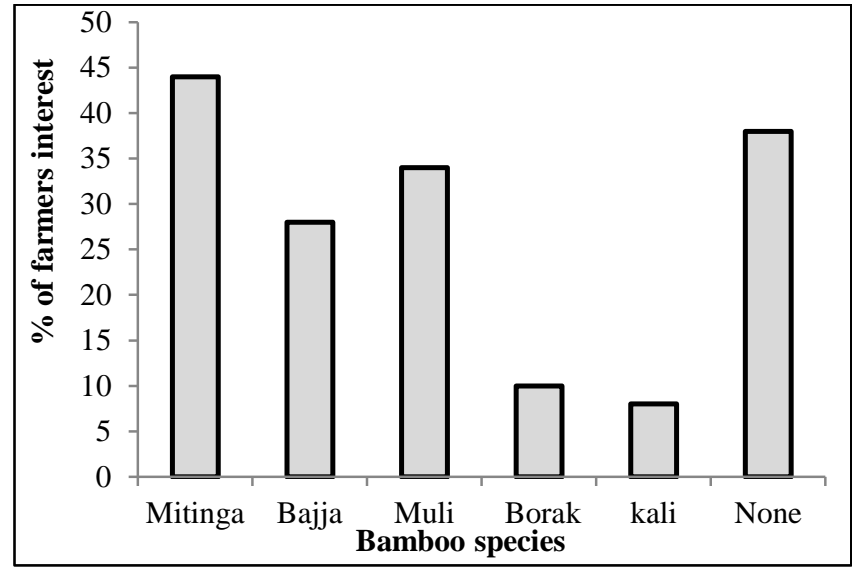

Fig. 6. Farmers' interest on bamboos.

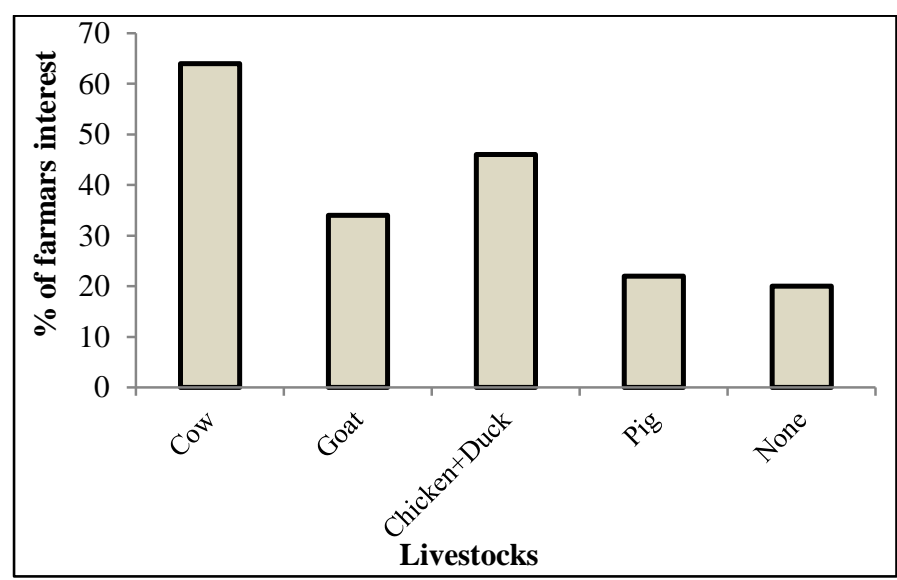

Fig. 7. Farmers' response on livestock.

Moreover, the other species such as Guava, Blackberry, Lemon, Wood apple, Palm, Litchi etc. are also used significantly for their nutritious and timber value. These various homestead species play an important role to increase the diversified income of the respondents which contribute to reduce their poverty to some extent. The farmers are very much interested on non-timber bamboo species cultivation. As a first growing non-timber species bamboo has an important role in the cropping pattern in the hilly region of Bangladesh. The current data represents that $44 \%$ of the farmers have bamboo clumps but $24 \%$ have no bamboos. The dominant bamboo species are Mitinga (Bambusa tulda Roxb.) followed by Muli (Melocanna baccifera (Roxb.) Kurz.) in the study area (Fig. 6). 
Bamboos play a vital role in soil conservation in the hilly region. Due to the extensive root and rhizome system bamboo effectively can bind $33 \mathrm{~cm}$ of top soil which is critical for soil health. Because of the dense surface roots, bamboos provide protection against sheet and gully erosion more effectively than of the most other tress. A single bamboo plant could bind up to $6.0 \mathrm{~m}^{3}$ soil. Besides a bamboo clump can protect up to $12 \mathrm{~m}^{3}$ of river embankment. An expansion of bamboo plantation, especially on the exposed and degraded slopes can help in preventing many potential disasters in mountain areas. In China vast areas of hilly regions are covered by bamboos, which form a green protective cover. These results in minimal erosion, and streams and rivers flowing in these regions remain clear of suspended silt (Banik 2000).

Table 1. Survival and growth performance of different bamboo species in farmers' land and homestead.

\begin{tabular}{llccc}
\hline Bamboo species & Planting date & Survival \% & Ave. no. of shoots/clump after 8 months & Average culm height (ft) \\
\hline Baijja & October 2017 & 98 & 9.3 & 27.20 \\
Ora & October 2017 & 100 & 23.5 & 20.00 \\
Tatua & October 2017 & 95 & 11.3 & 15.50 \\
Bhudum & October 2017 & 95 & 8.5 & 10.50 \\
\hline
\end{tabular}

Bamboos along roadsides can reduce the surface erosion and the small landslides that fill the drains or blocks. In combination with selected trees that can penetrate root to a greater depth bamboo provide a low cost means of slope stabilization in the hilly areas. Based on the farmers response and the land use system in the study site, 4,000 bamboo seedlings of four important species such as Baijja (Bambusa vulgaris Schrad.), Bhudum (Dendrocalamus gigantieus Munro), Ora (Dendrocalamus longispathus (Kurz) Kurz) and Tetua (Bambusa jaintiana R.B. Majumdar); fruit crops lemon and betel nut, timber species hybrid Acacia and medicinal plant Aloe vera and diabetic plants (Gynura procambens (Lour.) Merr) were distributed among the 60 selected farmers under this study programme. Twelve hectares bamboo plantations were raised in farmers' field and homestead with the combination of other timber, non-timber, fruits and annual vegetable species as a part of the improved farm practices. The survival and growth performance of different bamboo species both in homestead and field was found highly satisfactory. In average, 95\% seedlings were survived and each seedling produced a number of new shoots to form a clump within six months. The results revealed that average 23.5 shoots/clump were recorded in Ora bamboo with an average height $20.00 \mathrm{ft}$ followed by Tatua, Baijja and Bhudum bamboo(Table 1).

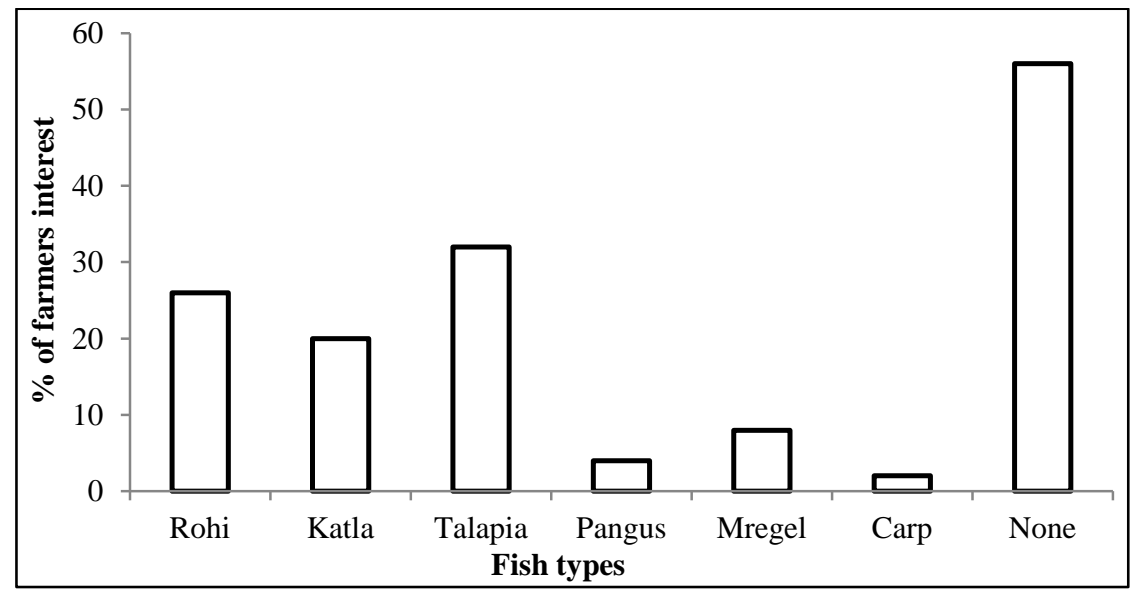

Fig. 8. Farmers' response on fish cultivation.

It has been estimated that each bamboo clump would produce at least 10 mature bamboos within next three years. Farmers will be able to extract 5-6 mature bamboos from each clump after five years of 
plantation. It has also been calculated that each farmer has 33 bamboo clumps from which they will get 165 mature bamboos in the first year. Some extent farmers produced seasonal vegetables like bean, chili, ladies finger, sweet gourd, the year round fruits papaya and banana as inter cropping with bamboos up to three years. Besides, they were planted bamboos with the fruit tree mango and timber tree such as Acacia (Acacia auriculiformis), Eucalyptus (Eucalyptus camaldulensis), Garjon (Depterocarpus sp.), Teak (Tectona grandis), Gamar (Gmelina arborea) and Rubber (Hevea brasiliensis) also in the same area of plantation. The practice of diversified cropping system in the hilly area also effects on the livestock and fish culture of the targeted households. It was noticed that the status of livestock and fish cultivation were significantly increased up to $64 \%$ and $32 \%$ respectively during the study period. The status of livestock and fisheries are presented in Fig. 7 and Fig. 8, respectively.

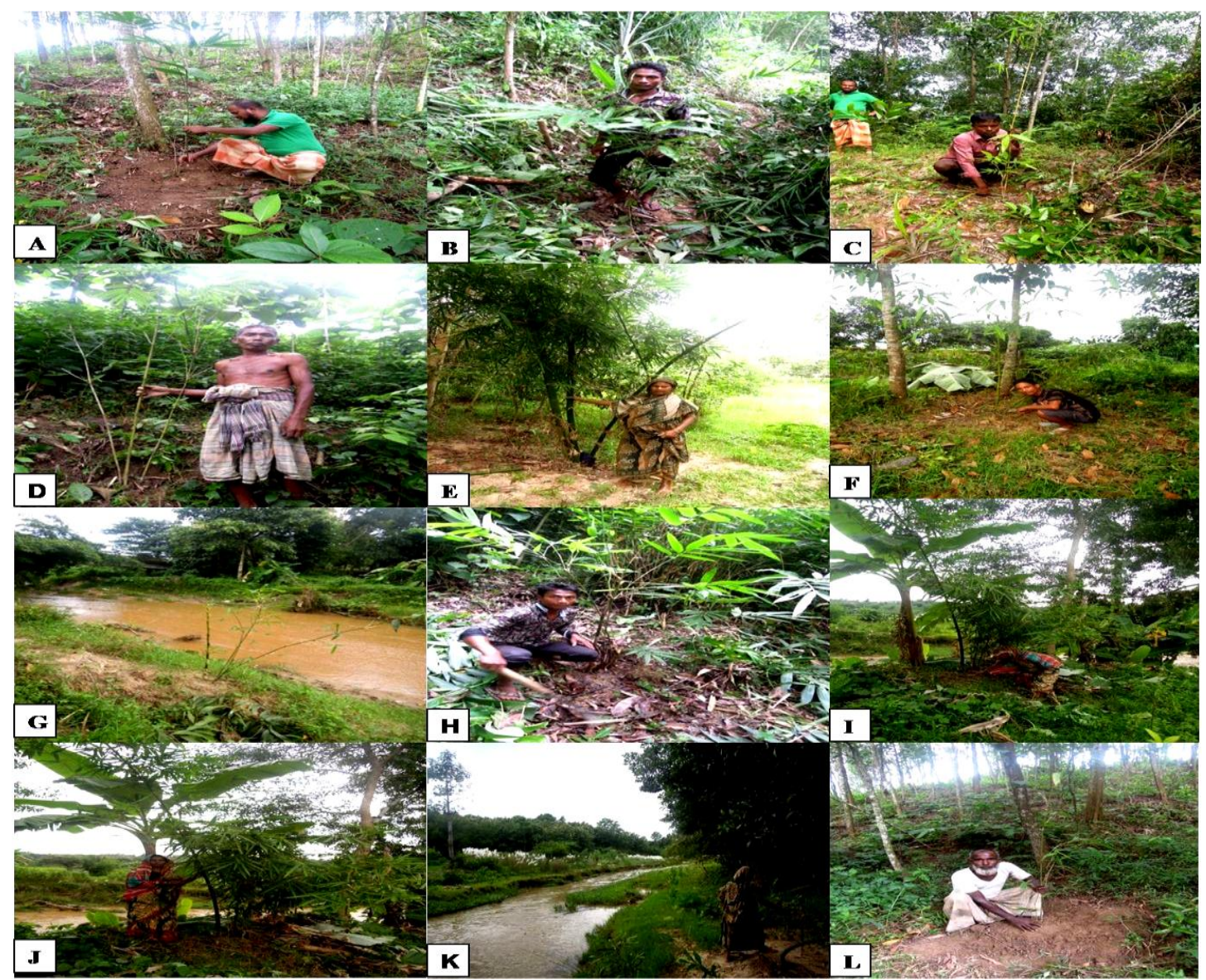

Fig. 9. Intercropping pattern practice in the study area: A. Bamboo and fruit crop papaya; B. Bamboo and timber species acacia; $\mathbf{C}$ and D. Bamboo plantation at canal side; $\mathbf{E}$ and $\mathbf{F}$. Bamboo and banana at canal side; $\mathbf{G}$ and $\mathbf{H}$. Bamboo plantation at homestead; and $\mathbf{I}, \mathbf{J}, \mathbf{K}$ and $\mathbf{L}$. Bamboo, mango tree, banana and timber species at hill base.

So, these results indicated that it is due to the earning of the farmers from the new farming system practiced in their homestead and cropland. The main problems in farm practices of the hilly region were found the lack of knowledge, supply of quality seeds and seedlings, fertilizers, pesticides and the scarcity of water for irrigation. Farmers of the study site used to practice traditional $\mathrm{jhum} / \mathrm{shifting}$ cultivation as they had a little knowledge of multi-cropping or agroforestry practices before the intervention of the current study. Later on the farmers realized the importance of the cultivation of perennial timber, non-timber and fruit plants along with annual agricultural crop and its contributions to 
their household economy. Now they have been practicing multi-cropping systems i.e. combination of annual and perennial crops in their homestead and cropland. This diversified cropping pattern like as (i) Bamboo + Pineapple + Lemon + Betel nut, (ii) Bamboo + Jackfruit + Mango + Lemon + Betel nut, (iii) Bamboo + Lemon + Betel nut + Papaya, (iv) Bamboo + Lemon + Banana + Papaya, (v) Bamboo + Banana + Lemon + Litchi, (vi) Bamboo + Banana + Bean + Papaya, (vii) Bamboo + Chili + Potato + Sweet guard, (viii) Bamboo + Acacia + Hybrid acacia, and (ix) Bamboo + Eucalyptus (Fig. 9).

According to Islam et al. (2012) perennial crops along with annual crops is getting popularity day by day due to its diversified contributions to socio-economic conditions. This practice is accepted socially and ecologically by the local people. The hilly region of Bangladesh is increasingly threatened by environmental degradation. This adversely affects not only land and biodiversity but also the livelihood of the hill forest dwellers as a whole. Sustainable development in the CHTs is closely related to the scientific management of the hill forest resources. The improved hill farming/agroforestry technologies are important in this regard. Paul et al. $(1996,2005)$ recognize the high magnitude of soil erosion 30-70 $\mathrm{t} / \mathrm{ha} / \mathrm{y}$ even more in traditional hill farming practices whereas the rate is low (16-22 t/ha/y ) in the improved hill farming practices. Similarly, the intensity of soil run-off is lower and infiltration rate is higher under improved hill farming practices (Kisha, 2005).

There is a great scope of developing different agro-forestry systems in the hill areas of Bangladesh. Now a days, the farmers are very much interested in intercropping system. They have been realizing the benefits of integrated farming system i.e., agroforestry and its impacts are quite obvious in their socioeconomic status. By the proper implementation of agroforestry practices, the peoples of the area can improve their livelihood in a sustainable way.

The farmers perceived a positive attitude towards adopting improve farm practices to get better return than their traditional practices. They found that it could be minimized the risk of damaging one crop by the other crop through practicing multi-cropping system. They have the opportunities to earn all year round from the same unit of land. It was found that, some of the farmers earned extra cash money ranging from 4,000-10,000 BDT within three months by selling seedlings and agricultural products. This extra income supportd them to meet their daily expenses. In consideration of the income status of the target farmers it might be reckoned that, the introduction of the agroforestry practices (croplands and homesteads agroforestry) of Sarai Union of Lama would play an important role in the economic development of the local farmers. These increased incomes also facilitate the respondents to improve their living status which provide them better access for food, education, shelter, health and clothing. The increased production facilitated the villagers to reduce their poverty in some extent and thus they had better access to their daily necessities which helped them to attain a minimal standard of living.

It has been observed that the farmers of the study area are now very happy in adopting new farming system instead of their traditional practice. They perceived that the multi-cropping farming system is a more profitable land use system in the hilly area. It also contributed them in many ways, such as: improving income, educational status, housing condition, homestead tree species status, household assets, sanitation condition, production of agricultural crops, etc. Their attitude and perception on diversified cropping is very much supportive to promote and upscale the farming system in the study area. Therefore, the current study may conclude that the practice of developed new cropping pattern in the hilly region would contribute in reducing poverty of the hill farmers. The subsistence and commercial uses of diversified products and services of multi-cropping in the same unit of land secured the food production, protecting a sound environment and conserving the biodiversity. This also helps to conserve and protect traditional forest resources. 


\section{ACKNOWLEDGEMENTS}

The authors would like to express their thanks to Bangladesh Agricultural Research Council (BARC) for financial assistance. They are also grateful to the Director of Bangladesh Forest Research Institute for providing the logistic supports during the study period.

\section{REFERENCES}

Banik, R. L. 2000. Silviculture and field guide to priority bamboos of Bangladesh and south Asia. Bangladesh Forest Research Institute, Chattogram, Bangladesh., pp. 1-80.

Garrity, P. D. 1999. Contour farming based on natural vegetative strip: expanding the scope for food crop production on sloping lands in Asia. Proc. of the Conference on Sustainable Agriculture. 26-30 April 1999, Bellagio, Italy. 8 pp.

Islam, M. W., M. M. Islam and M. N. Sadath. 2012. Contributions of Agroforestry Practice Towards Reducing Poverty at Keshabpur Upazila of Jessore District - A Case Study. J. Environ. Sci. Natural Resour. 5(2): 267-274.

Khan, N. A. and M. Millate-e-Mustafa. 2001. The State of Forestry in Bangladesh. The Bangladesh Observer. 16 September 2001.

Kisha, S. K. 2005. Contour hedgerow intercropping agroforestry technology for degraded hilside farms in Chittagong Hill Tracts. Proc. of National Workshop on Agroforestry Research. 16-17 September, 2001, BARI, Joydevpur, Gazipur, Bangladesh., pp.179-184.

Nair, P. K. R. 1984. Soil productivity aspects of agro forestry. ICRAF, Nairobi, Kenya. 85 pp.

Paul, S. P., M. Shamsuddin and A. T. M. E. Hossain. 1996. An evaluation of soil erosion status at FSRD site, Bandarban. In proc of 14th International Symposium on sustainable farming system. 11-16 November, 1996, Colombo, Sri Lanka., pp 101-106.

Paul, S. P. 2001. Sloping Agro forestry Land technology and Some Other Appropriate Hill Farming Systems. In: S. K. Bose and J. M. Roshetko (eds.). Sloping Agro forestry Land Technology. BFRI, Chittagong, Bangladesh., pp. 11-17.

Paul, S. P. and A. T. M. E. Hossain. 2005. Agroforestry research and development in the hill region of Bangladesh: experiences, problems and research needs. Proc. of national workshop on agroforestry research. 16-17 September 2001, BARI, Joydevpur, Gazipur, Bangladesh., pp. 185-192.

Young, A. 1989. Agroforestry for Soil Conservation. CAB International, Wallingford, Oxon, UK. 276pp. 